\title{
HYBRID SYSTEM SIMULATION TO SUPPLY HEATED AIR TO A SOLAR FOOD DRYER
}

\author{
Letícia J. Rodrigues $^{1 *}$, Diego M. Basso ${ }^{1}$
}

${ }^{1 *}$ Corresponding author. Universidade Federal do Rio Grande do Sul/ Porto Alegre - RS, Brasil.

E-mail: leticia.jenisch@mecanica.ufrgs.br | ORCID: https://orcid.org/0000-0002-8147-0770

\section{KEYWORDS}

electrical resistor arrangement, flat plate solar collector, auxiliary heating system, TRNSYS software.

\begin{abstract}
The intermittence of solar radiation, due to continuous rainy or cloudy days, is a limitation of simple and small solar dryers. These conditions often make them impossible to use. By including storage systems (thermal accumulation) and/or auxiliary energy sources, drying processes or dehydration can be conducted continuously, even during periods of low insolation. Therefore, the present work simulates and evaluates the thermal and energetic behavior of a hybrid system for heating the air that is directed to the dehydration chamber of a solar food dryer. The software selected for the simulation was TRNSYS. The simulated hybrid system consists of a flat plate solar collector and an arrangement of electrical resistors that guarantee the entry of air, at a constant temperature, into the dehydration chamber. The target temperature selected is $70{ }^{\circ} \mathrm{C}$, and the absence of food products in the chamber is assumed. An arrangement with four electric resistors totaling $1900 \mathrm{~W}$, with three different powers of $1000 \mathrm{~W}, 500 \mathrm{~W}$, and $200 \mathrm{~W}$ proved adequate to guarantee the entrance of air at a constant temperature when considering the climatic conditions of a city in the South of Brazil.
\end{abstract}

\section{INTRODUCTION}

Solar energy is commonly used for the sustainable development of the agricultural sector, standing out as a viable option, particularly in remote rural areas (Mekhilef et al., 2013). A direct application is drying, which reduces spoilage of food after harvest. This technique is widely used in developing countries (Mohanraj \& Chandrasekar, 2008; Queiroz et al., 2011; Shamekhi-Amiri et al., 2018) because of its low cost, low payback time (El Hage et al., 2018), and for providing increased income to small producers in a sustainable manner.

However, the intermittent behavior of solar radiation and the climatic conditions of the site do not allow the continuous functioning of solar dryers. These characteristics make continuous dehydration of the food impossible, resulting in incomplete dehydration, an unsuitable product, or a product with unsatisfactory characteristics for consumption. The complete drying process, in most cases, is longer than the daily insolation period (El Hage et al., 2018). Thus, for the simpler solar dryers, the challenge is to ensure that the drying process is continuous, irrespective of periods of low insolation, such as cloudy or rainy days, and no insolation at night.
In the last decades, several studies have been conducted (Ekechukwu \& Norton, 1999; Murthy, 2009; El-Sebaii \& Shalaby, 2012; El Hage et al., 2018; Lamidi et al., 2019; Anannob et al. 2020). Most of them aim to increase the efficiency of solar dryers and even allow their nocturnal use (Queiroz et al., 2011; El Khadraoui et al., 2017), focusing on modeling (Prakash et al., 2016; Dhanushkodi et al, 2017; Anannob et al. 2020), in the simulation (Hernandez et al., 2016; Sonthikun et al., 2016; Basso, 2017), and the experiment (Pangavhane et al., 2002; Mohanraj \& Chandrase kar, 2008; Amer et al., 2010; Okoroigwe et al., 2013; Sonthikun et al., 2016; Bhardwaj et al., 2017; Shamekhi-Amiri et al., 2018) of different types of solar driers and sustainable drying techniques.

For example, solar dryers with an auxiliary power source need less time to reach the desired humidity levels (Mekhilef et al., 2013). Among the auxiliary energy sources, biomass (Okoroigwe et al., 2013; Sonthikun et al., 2016; Dhanushkodi et al., 2017) and electricity (Amer et al., 2010) stand out. Indirect drying with natural convection (Pangavhane et al., 2002) or forced drying (Mohanraj \& Chandrasekar, 2008) provide better quality products than direct drying, in which the product is exposed to the sun. Also, forced convection shortens the

\footnotetext{
${ }^{1}$ Universidade Federal do Rio Grande do Sul/ Porto Alegre - RS, Brasil.
} 
drying time. Regarding thermal energy storage systems, water reservoirs (Queiroz et al., 2011), water reservoirs with electrical resistors and heat exchangers (Amer et al, 2010), sand (Mohanraj \& Chandrasekar, 2008), stone bed (Shamekhi-Amiri et al., 2018), granite bed (Nemś et al., 2018), and materials with phase change - PCM (Kant et al., 2016), such as paraffin (Bhardwaj et al., 2017; El Khadraoui et al., 2017), can be used.

Therefore, the use of an auxiliary energy source and/or a thermal energy storage system, such as thermoaccumulation, is presented as an alternative to minimize the effects arising from the intermittence and seasonality of solar radiation. However, for simple solar dryers, it is important to highlight that their main characteristics (low cost, easy handling, and inexpensive maintenance) should be maintained, particularly for applications in remote rural areas.

In this context, this study aims to perform the thermal and energy evaluation of a hybrid air heating system through simulation. Using this system, we aim to ensure the entry of air, at a constant temperature, into the dehydration chamber. The system comprises a flat plate solar collector and an electrical resistor and is simulated in the TRNSYS software (Klein et al., 2014).

\section{MATERIAL AND METHODS}

The simulated model, shown in Figure $1 \mathrm{C}$, is similar to a prototype, shown in Figures $1 \mathrm{~A}$ and 1B, which does not yet have a hybrid heating system and is located in the metropolitan region of Porto Alegre, RS, Brazil. The climate of this region is humid subtropical and presents the four well-defined seasons of the year. However, it shows great variability in the elements of meteorological weather because it is located in a transition zone. The most covert season of the year starts around May 1 and ends in early February.

The simulated solar collector is of the flat plate type, with a simple glass cover similar to the prototype collector shown in Figure 1A. The air circulation takes place under the absorber plate, and the flow is forced, as shown in Figure 1B. It also has constant flow of $0.028 \mathrm{~kg}$ $\mathrm{s}^{-1}$ (Basso, 2017). Its dimensions are $2 \mathrm{~m}$ long by $1 \mathrm{~m}$ wide. The geographical north orientation and $42^{\circ}$ slope used in the simulation are the same as the prototype.
A.

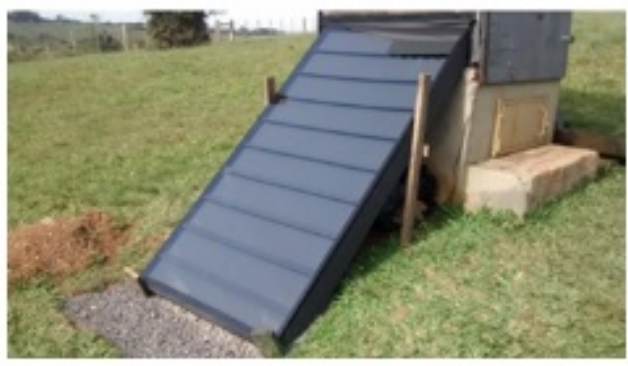

B.

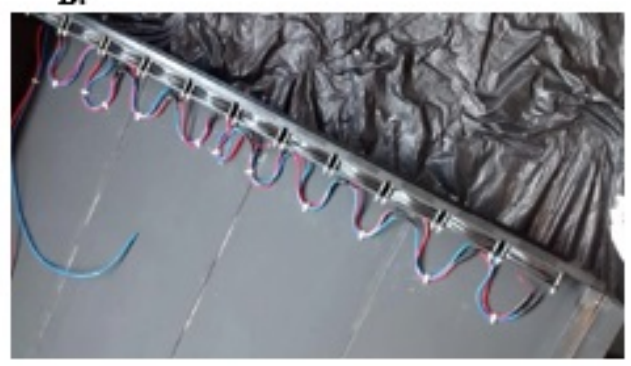

C.

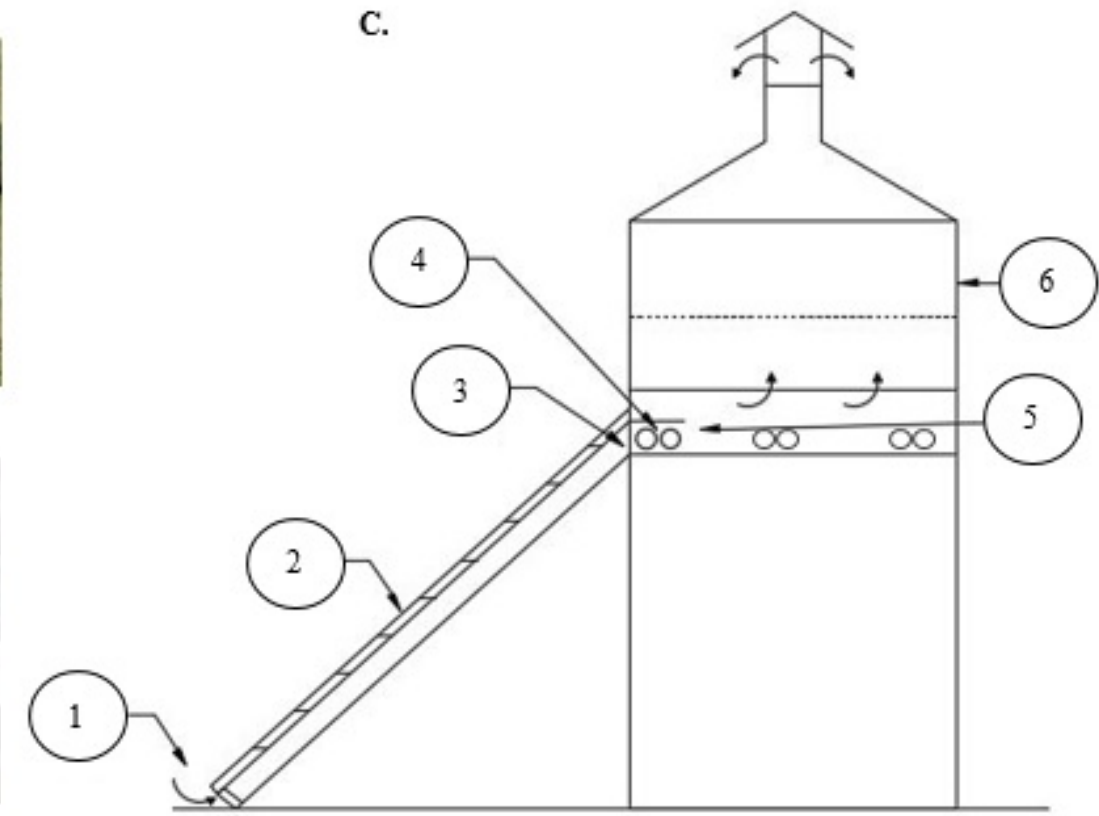

FIGURE 1. Prototype solar collector (A) and forced ventilation system (B). Model used in the simulation (C): (1) collector inlet and forced ventilation system, (2) flat plate solar collector, (3) collector outlet, (4) electrical resistor arrangement, (5) plenum, and (6) dehydration chamber.

The simulated hybrid heating system consists of the solar collector (items 1 to 3 of Figure 1C) and a set of electrical resistors (item 4 of Figure 1C) coupled from its output (item 5 of Figure 1C). The evaluation is carried out using the TRNSYS software, which simulates the behavior of systems on a transient basis for a period of one year on an hourly basis and for a total of 8760 hours. The software has a modular structure and each component, Type, models the operation of a part of the system (Klein et al., 2014)
The meteorological data are obtained directly from the TRNSYS software database for the city of Porto Alegre (latitude $30^{\circ} 1^{\prime}$ South and longitude $51^{\circ} 13^{\prime} 43^{\prime \prime}$ West). These data are generated by the Meteonorm software (Klein et al., 2014)

To model the hybrid system shown in Figure 2, the following Types were used: weather data (Type15), flat plate solar collector with simple glass cover (Type561), energy integrator (Type24), output data export (Type25), electrical resistor arrangement (Type930), and schedule (Type14h). 


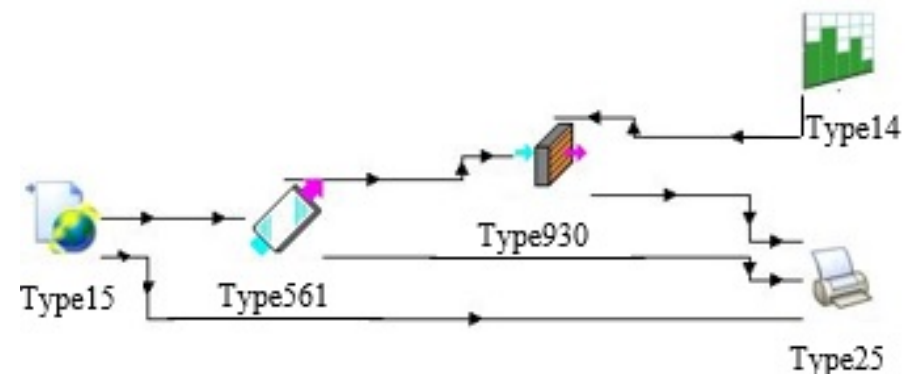

FIGURE 2. Type Arrangement used in the hybrid heating system simulation.

The temperature used in the drying process of food products varies according to the type of product and, in some cases, for the same product different drying temperatures are used, as studied in Cruz et al. (2012). The value for the target temperature, $\mathrm{T}_{\text {set }}$, of $70{ }^{\circ} \mathrm{C}$ was selected based on the following works available in specialized literature: Queiroz et al. (2011), Corrêa et al. (2015), Basso (2017), and Nunes et al. (2017). In such cases, the temperature of $70{ }^{\circ} \mathrm{C}$ was among the temperatures used for different types of food products.

\section{RESULTS AND DISCUSSION}

Three days were selected for the thermal and energy evaluation of the hybrid system. These days

A.

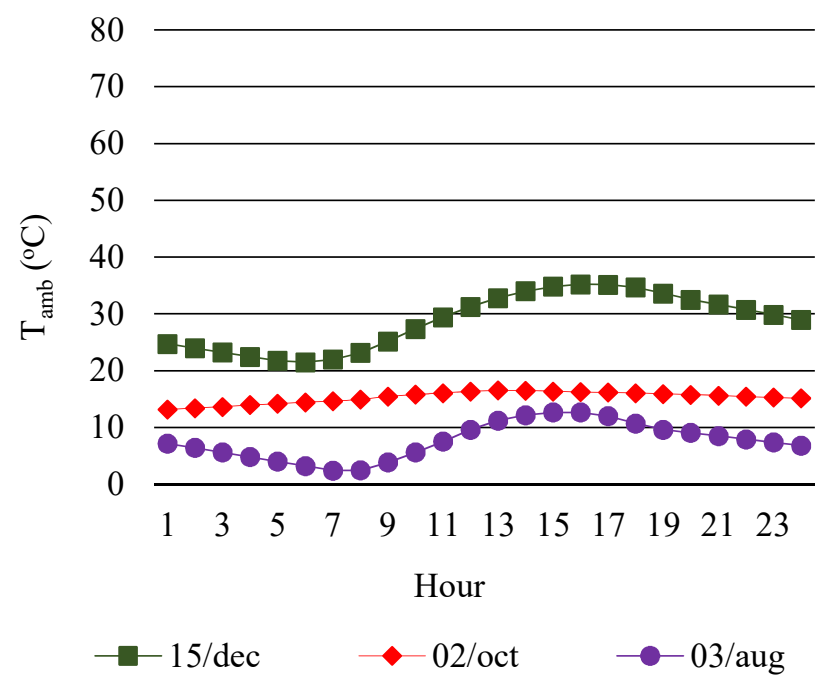

represent the following situations: day when there was the largest demand of extra energy (Aug/03), day when there was the smallest demand of extra energy (15/Dec), and day when there was the largest constant demand of extra energy $(02 / \mathrm{Oct})$, in the period between $8 \mathrm{~h}$ and $18 \mathrm{~h}$ in real solar time.

The daily profile of the ambient temperature $\left(\mathrm{T}_{\mathrm{amb}}\right)$ for the three days is shown in Figure 3A. The daily temperature profiles of the absorber plate $\left(T_{p}\right)$ which is part of the collector, and the air temperature at the outlet of the collector $\left(\mathrm{T}_{\text {air }}\right)$ are shown in Figures 3B (Aug/03), 3C (Dec/15), and 3D (Oct/02), respectively.

B.

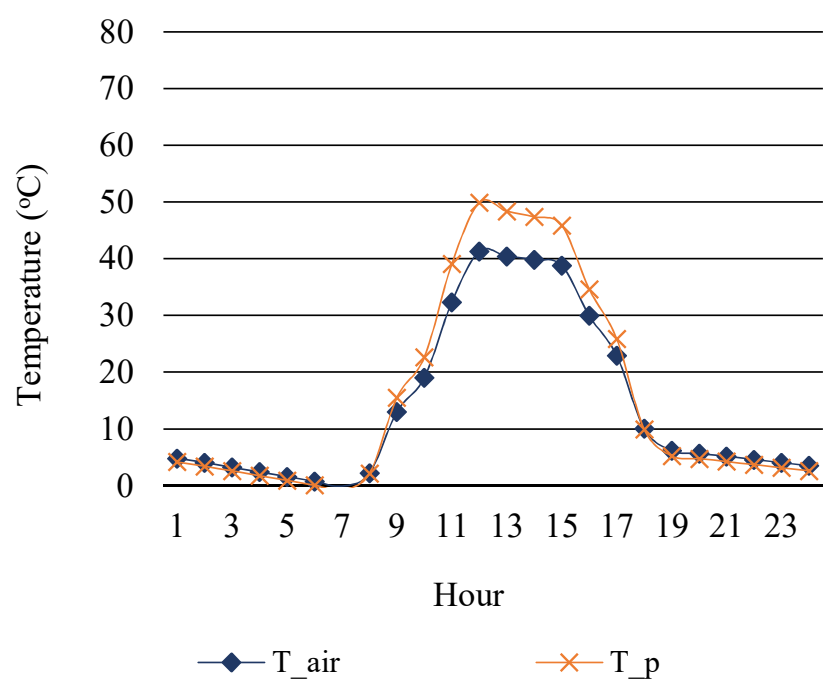


C.

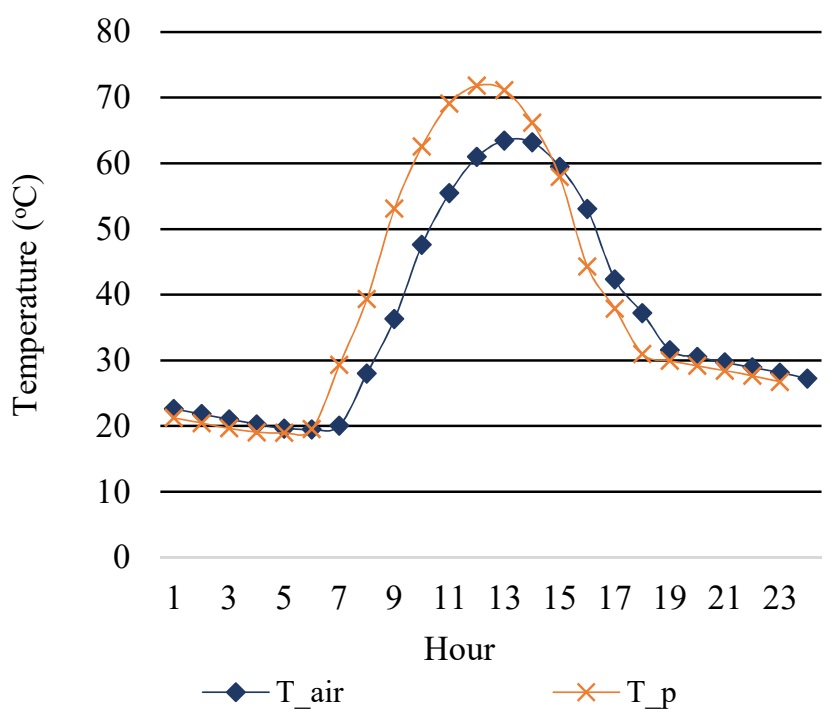

D.

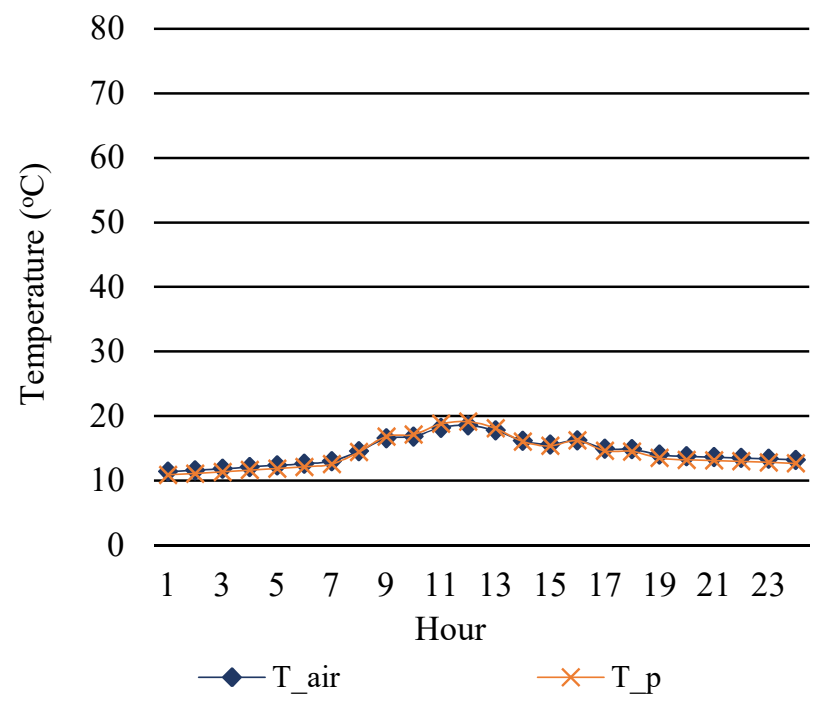

FIGURE 3. Ambient Temperature $\left(T_{a m b}\right)$, Plate Temperature $\left(T_{p}\right)$, and Air Temperature $\left(T_{\text {air }}\right)$ in (A) three days, (B) August 3, (C) December 15, and (D) October 2.

The cloudy day is the one that presents the smallest difference between the maximum and minimum $\mathrm{T}_{\mathrm{amb}}, 1.6$ ${ }^{\circ} \mathrm{C}(\mathrm{Oct} / 02)$, in contrast with the days of greater irradiation, in clear sky conditions, $10.2{ }^{\circ} \mathrm{C}$ (Aug/03) and $12.1{ }^{\circ} \mathrm{C}$ (Dec/15), as shown in Figure 3A. Regarding the maximum difference between $\mathrm{T}_{\mathrm{p}}$ and $\mathrm{T}_{\text {air }}$, we have $8.6{ }^{\circ} \mathrm{C}$ in Aug/03, $8.4{ }^{\circ} \mathrm{C}$ in Dec $/ 15$, and $0.6{ }^{\circ} \mathrm{C}$ in Oct $/ 02$.

The difference is $2.8{ }^{\circ} \mathrm{C}$ when assessing the maximum difference between $T_{p}$ and $T_{a m b}$ for the day of low irradiation. That is, the value of $T_{p}$ is very close to the value of $\mathrm{T}_{\mathrm{amb}}$ throughout the day, so that the rate of heat transfer (losses) between the collector and the environment is practically negligible, which is desirable.

However, the small maximum difference between $\mathrm{T}_{\mathrm{p}}$ and $\mathrm{T}_{\text {air }}$ results in a negligible heat transfer rate for air heating. Therefore, in situations like these, much if not all, of the energy needed to heat the air must be supplied by the auxiliary heating system.

For clear sky days, the heat transfer rate between the plate and the air is higher, even though there is a greater loss of energy from the collector to the environment, as the maximum differences between $\mathrm{T}_{\mathrm{p}}$ and $\mathrm{T}_{\text {amb }}$ are $40.3{ }^{\circ} \mathrm{C}$ in $\mathrm{Aug} / 03$ and $39.0{ }^{\circ} \mathrm{C}$ in Dec/15. In these situations, the solar collector is able to deliver some of the energy needed to heat the air.

The maximum values of $\mathrm{T}_{\text {air }}$ are $41.3{ }^{\circ} \mathrm{C}$ on $\mathrm{Aug} / 03$, $63.5^{\circ} \mathrm{C}$ on Dec/15, and $18.5{ }^{\circ} \mathrm{C}$ on Oct/02. In only one of the three days selected, the maximum $\mathrm{T}_{\text {air }}$ arrives close to the value of $\mathrm{T}_{\text {set. }}$. This result shows that the flat plate solar collector alone is not enough to guarantee the heating of the air up to $\mathrm{T}_{\text {set}}$, even on the day with the highest daily direct irradiation in the collector plane. That is, without the hybrid system (Sun + auxiliary energy source) the dryer is not able to provide the thermal conditions for continuous dehydration.

Concerning solar radiation, the software provides the energy incident in the collector plane every hour per area unit, instead of the flow (irradiance, $\mathrm{G}$, in $\mathrm{W} \mathrm{m}^{-2}$ ), which is instantaneous. Thus, the concept of mean hourly irradiance, $\mathrm{G}_{\mathrm{m}}$, in $\mathrm{W} \mathrm{m}^{-2}$, is defined as the ratio between the direct hourly irradiance in the collector plane and the period of one hour. The behavior of $\mathrm{G}_{\mathrm{m}}$ is shown in Figure 4A. 
A.

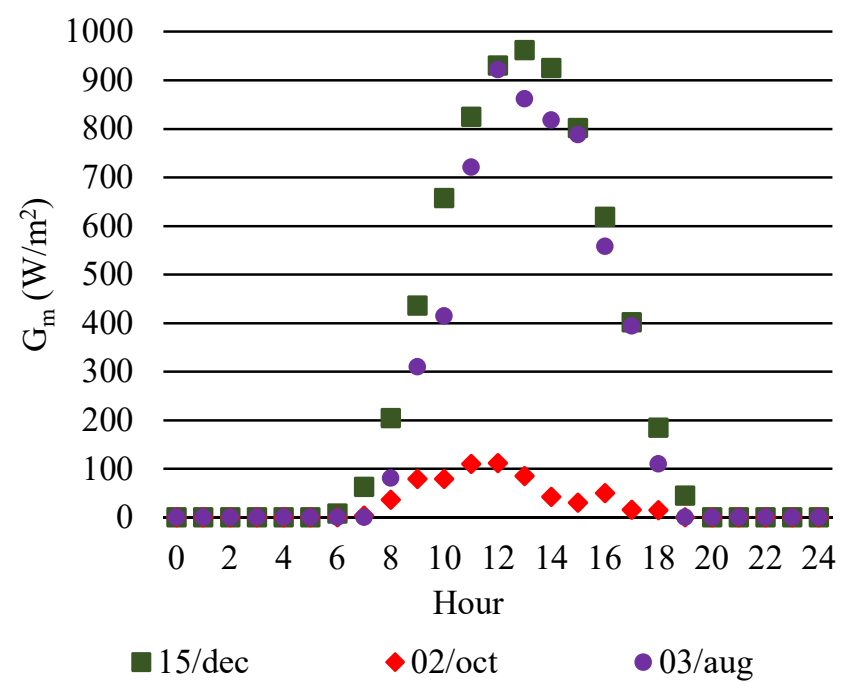

C.

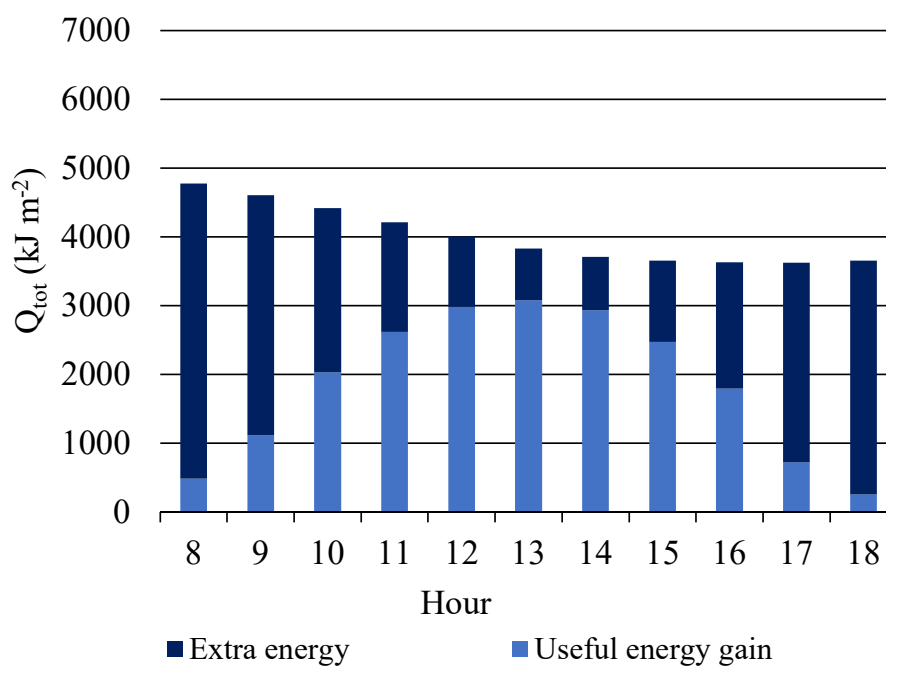

B.

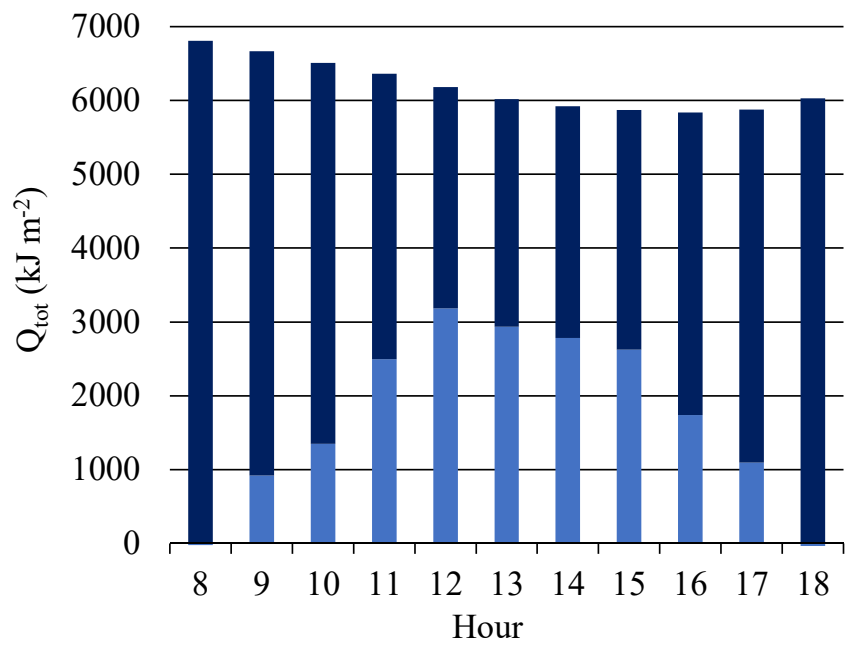

- Extra energy $\quad$ Useful energy gain

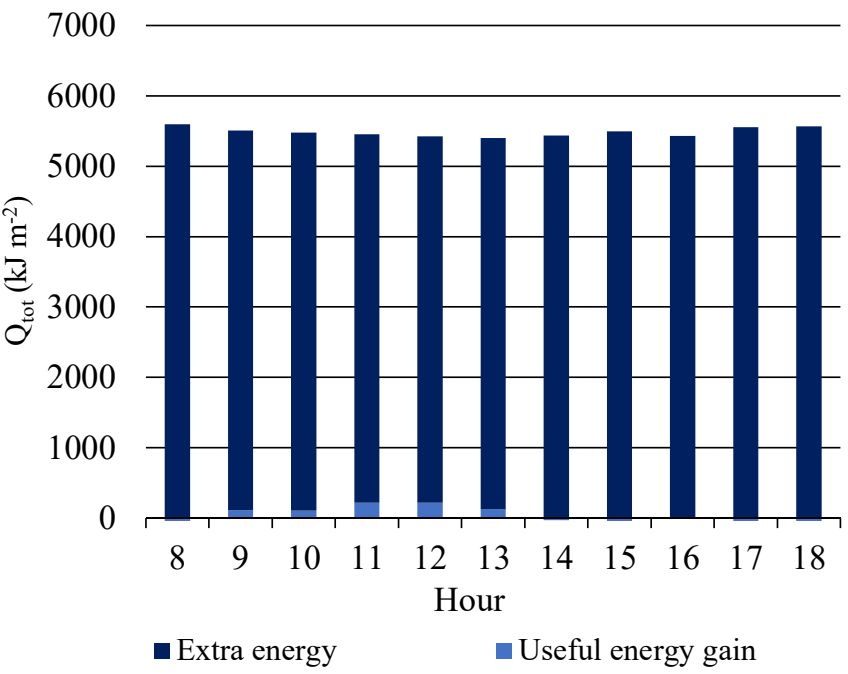

FIGURE 4. Mean hourly irradiance in the collector plane $(A)$ and total hourly energy $\left(\mathrm{Q}_{\text {tot }}\right)$ presented in terms of extra energy and useful energy gain for August 3 (B), December 15 (C), and October 2 (D).

In the case of August 3, the maximum value of Gm $\left(922 \mathrm{~W} \mathrm{~m}^{-2}\right)$ occurs at $12 \mathrm{~h}$, as seen in Figure 4A. The useful energy gain, that is, the net rate at which energy is transferred to the fluid through the solar collector (Klein et al., 2014), is shown in Figure 4B. As expected, the behavior of the useful energy gain resembles the irradiance behavior, reaching the maximum value of $3183 \mathrm{~kJ} \mathrm{~m}^{-2}$ at $12 \mathrm{~h}$. That same behavior is observed on the other days.

The total hourly energy $\left(\mathrm{Q}_{\mathrm{tot}}\right)$ is the energy required to raise $T_{\text {air }}$ to $T_{\text {set }}$ temperature within one hour. That is, it is the sum of the useful energy gain and extra energy, with the latter being supplied by the auxiliary system. In the present case, the largest extra hourly energy demand occurs at 8 a.m. $\left(6808 \mathrm{~kJ} \mathrm{~m}^{-2}\right)$ while the smallest demand occurs at 12 p.m. $\left(3000 \mathrm{~kJ} \mathrm{~m}^{-2}\right)$, as shown in Figure 4B.

$\mathrm{Q}_{\text {tot }}$ 's behavior throughout the evaluated period is what is expected for a clear day, decreasing throughout the day due to the thermal inertia of the system. However, due to the significant difference between $\mathrm{T}_{\text {amb }}$ and $\mathrm{T}_{\text {set }}$, the amount of energy needed for heating the air is greater than the amount needed for day Dec/15, as shown in Figure 4C.
On this day, the ambient temperature is higher and, consequently, the energy required for heating the air will be lower than in other cases. The largest demand for extra energy occurs at 8 a.m. $\left(4291 \mathrm{~kJ} \mathrm{~m}^{-2}\right)$ and the smallest demand occurs at 1 p.m. $\left(748 \mathrm{~kJ} \mathrm{~m}^{-2}\right)$, as seen in Figure 4C. The useful energy gain reaches its maximum at $1 \mathrm{pm}\left(3808 \mathrm{~kJ} \mathrm{~m}^{-2}\right)$.

For day Oct $/ 2$, it can be observed that the useful energy gain value is practically zero. As $T_{a m b}$ is practically constant and of low value, $\mathrm{Q}_{\text {tot }}$ remains nearly constant throughout the day, around $5000 \mathrm{~kJ} \mathrm{~m}^{-2}$.

As in the thermal analysis, the energy analysis from Figures $4 \mathrm{~B}, 4 \mathrm{C}$, and $4 \mathrm{D}$ show that the heating provided by the solar collector alone is not enough to heat the air to the $T_{\text {set }}$ temperature. We again see the need to use an auxiliary system.

As previously mentioned, the auxiliary power source is electrical (set of resistors) with variable power. In this sense, knowing the extra energy required, it is possible to determine the mean power $\left(\mathrm{P}_{\mathrm{m}}\right)$ of the set of resistances for each hour, as stated in Table 1, and scale the hybrid system. The maximum and minimum values of $\mathrm{P}_{\mathrm{m}}$ are between 208 $\mathrm{W}$ and $1891 \mathrm{~W}$. 
TABLE 1. Ratio between the extra energy and the total hourly energy, and the respective mean power of the electrical resistances $\left(\mathrm{P}_{\mathrm{m}}\right)$ for each hour of the simulated days.

\begin{tabular}{ccccccc}
\hline \multirow{2}{*}{ Schedule } & \multicolumn{2}{c}{$\mathbf{A u g} / \mathbf{0 3}$} & \multicolumn{2}{c}{$\mathbf{O c t} / \mathbf{0 2}$} & \multicolumn{2}{c}{ Dec/15 } \\
\cline { 2 - 7 } & $\begin{array}{c}\mathbf{Q}_{\mathbf{e}} / \mathbf{Q}_{\text {tot }} \\
\mathbf{( \% )}\end{array}$ & $\begin{array}{c}\mathbf{P}_{\mathbf{m}} \\
\mathbf{W})\end{array}$ & $\mathbf{Q}_{\mathrm{e}} / \mathbf{Q}_{\text {tot }}(\mathbf{\%})$ & $\begin{array}{c}\mathbf{P}_{\mathbf{m}} \\
(\mathbf{W})\end{array}$ & $\mathbf{Q}_{\mathrm{e}} / \mathbf{Q}_{\text {tot }}(\mathbf{\%})$ & $\begin{array}{c}\mathbf{P}_{\mathbf{m}} \\
(\mathbf{W})\end{array}$ \\
\hline $\mathbf{8}$ & 100 & 1891 & 100 & 1555 & 90 & 1192 \\
$\mathbf{9}$ & 86 & 1596 & 99 & 1501 & 76 & 969 \\
$\mathbf{1 0}$ & 79 & 1434 & 98 & 1492 & 54 & 663 \\
$\mathbf{1 1}$ & 61 & 1075 & 97 & 1456 & 38 & 442 \\
$\mathbf{1 2}$ & 49 & 833 & 96 & 1446 & 25 & 283 \\
$\mathbf{1 3}$ & 51 & 857 & 98 & 1468 & 20 & 208 \\
$\mathbf{1 4}$ & 53 & 873 & 100 & 1511 & 21 & 216 \\
$\mathbf{1 5}$ & 55 & 901 & 100 & 1527 & 32 & 328 \\
$\mathbf{1 6}$ & 70 & 1139 & 100 & 1509 & 51 & 510 \\
$\mathbf{1 7}$ & 81 & 1328 & 100 & 1544 & 80 & 805 \\
$\mathbf{1 8}$ & 100 & 1676 & 100 & 1546 & 93 & 944 \\
\hline
\end{tabular}

Since the selected days represent situations where there was the highest demand for extra power, lowest demand for extra power, and highest constant demand for extra power, a set consisting of two $200 \mathrm{~W}$ resistors, a 500 $\mathrm{W}$ resistor and a $1000 \mathrm{~W}$ resistor, totaling $1900 \mathrm{~W}$, is enough to supply the power needed to heat the air to $T_{\text {set }}$ for any day of the year.
Figure 5 presents the behavior throughout the year of the total energy in terms of useful energy gain and extra energy. In all months of the year, the use of the auxiliary heating system is required. The lowest demands for extra energy are in December and January, since the extra energy is equivalent to $55.3 \%$ of the total monthly energy. In June, we have the highest demand for extra energy, since the extra energy is equivalent to $88.5 \%$ of the total monthly energy.

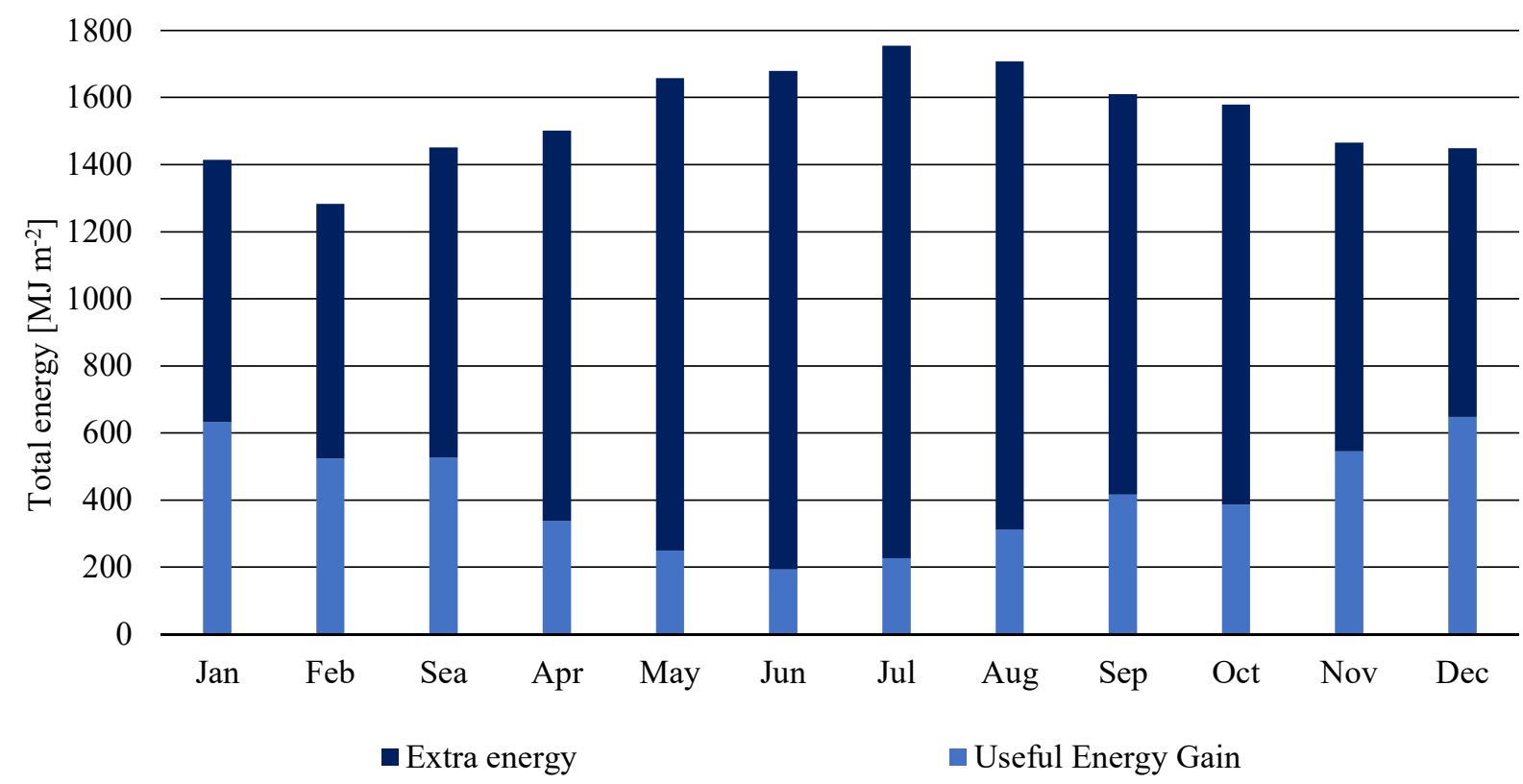

FIGURE 5. Annual profile of the total monthly energy in terms of useful energy gain and extra energy

Once the hybrid air heating system is installed, the solar dryer will be able to ensure that the drying process is continuous, regardless of periods of low insolation, such as cloudy or rainy days, or no insolation at all. The chosen auxiliary source, electrical resistors, meets the desirable characteristics for simpler solar dryers, i.e. low cost, easy handling, and inexpensive maintenance.

\section{CONCLUSIONS}

This study performed the thermal and energy evaluation of a hybrid air heating system through simulation. With this system, the aim was to guarantee the entry of air, at a constant temperature, into the dehydration chamber. This condition is of paramount importance, as it allows the continuous drying of food, avoiding incomplete dehydration and/or products outside the conditions proper for consumption.

For the type of simulated solar dryer, the use of an auxiliary air heating system proved to be mandatory. In no month of the year, the use of the solar collector alone is sufficient to heat the air to $70{ }^{\circ} \mathrm{C}$. In the best of the cases evaluated, the maximum air temperature at the collector 
outlet was equivalent to $90 \%$ of the target temperature. The energy evaluation confirmed the necessity of using this type of system and allowed the scaling of the electrical resistors.

The period in which there is the greatest demand for extra energy is between April and October. The highest demand occurs in June and the lowest demand occurs in December and January. From the energy analysis, a set-up consisting of four resistors, two of $200 \mathrm{~W}$, one of $500 \mathrm{~W}$, and one of $1000 \mathrm{~W}$ of power, totaling $1,900 \mathrm{~W}$, was designed. In the simulation, this arrangement was able to guarantee the entry of air at a constant temperature, equal to $70^{\circ} \mathrm{C}$, in the dehydration chamber.

In this manner, the dehydration of food can be performed continuously in periods of low insolation, such as cloudy or rainy days, with the use of the resistor arrangement. Nevertheless, the operating time of the dryer and the drying time can be increased, since the auxiliary heating system allows its operation in the first hours of the day and in the period before sunset, in which both have low insolation.

\section{ACKNOWLEDGEMENTS}

The authors would like to thank the Post Graduate Program in Mechanical Engineering, PROMEC, of the Federal University of Rio Grande do Sul, UFRGS, and the Coordination for the Improvement of Higher-Level Personnel, CAPES.

\section{REFERENCES}

Amer BMA, Hossain MA, Gottschalk K (2010) Design and performance evaluation of a new hybrid solar dryer for banana. Energy Conversion and Management 51(4):813820. DOI: https://doi.org/10.1016/j.enconman.2009.11.016

Anannob AA, Masuda MH, Dabnichkia P, Ahmedb A (2020) Design and numerical analysis of a hybrid geothermal PCM flat plate solar collector dryer for developing countries. Solar Energy 196:270-286. DOI: https://doi.org/10.1016/j.solener.2019.11.069

Basso DM (2017) Simulação do sistema de aquecimento de ar de um secador solar híbrido de produtos agroalimentícios usando o TRNSYS. MSc Thesis, Porto Alegre, Universidade Federal do Rio Grande do Sul. Available:

http://www.bibliotecadigital.ufrgs.br/da.php?nrb $=0010250$ $68 \& l o c=2017 \& 1=b 84 \mathrm{e} 29 \mathrm{e} 817 \mathrm{f} 833 \mathrm{c} 6$

Bhardwaj AK, Chauhan R, Kumar R, Sethi M, Rana A (2017) Experimental investigation of an indirect solar dryer integrated with phase change material for drying valeriana jatamansi (medicinal herb). Case Studies in Thermal Engineering 10:302-314. DOI: http://dx.doi.org/10.1016/j.csite.2017.07.009

Corrêa LC, Andrade ET de, Martinazzo AP, D’Andrea EM, Sousa FA de, Figueira VG (2015) Cinética de secagem, contração volumétrica e análise da difusão líquida do figo (Ficus carica L.). Revista Brasileira de Engenharia Agrícola e Ambiental 19(8):797-802. DOI:

http://dx.doi.org/10.1590/1807-1929/agriambi.v19n8p797-802
Cruz PMF da, Braga GC, Grandi AM de (2012)

Composição química, cor e qualidade sensorial do tomate seco a diferentes temperaturas. Semina: Ciências Agrárias 33(4):1475-1486. DOI: http://dx.doi.org/10.5433/1679$0359.2012 \mathrm{v} 33 \mathrm{n} 4 \mathrm{p} 1475$

Dhanushkodi S, Wilson VH, Sudhakar K (2017) Mathematical modeling of drying behavior of cashew in a solar biomass hybrid dryer. Resource-Efficient Technologies 3(4):359-364. DOI: https://doi.org/10.1016/j.reffit.2016.12.0

Ekechukwu OV, Norton B (1999) Review of solar-energy drying systems II: an overview of solar drying technology. Energy Conversion \& Management 40:615-655. DOI: https://doi.org/10.1016/S0196-8904(98)00093-4

El Hage H, Herez A, Ramadan M, Bazzi H, Khaled M (2018) An investigation on solar drying: A review with economic and environmental assessment. Energy 157:815829. DOI: https://doi.org/10.1016/j.energy.2018.05.197

El Khadraoui A, Bouadila S, Kooli S, Farhat A, Guizani A (2017) Thermal behavior of indirect solar dryer: Nocturnal usage of solar air collector with PCM. Journal of Cleaner Production 148:37-48. DOI:

http://dx.doi.org/10.1016/j.jclepro.2017.01.149

El-Sebaii AA, Shalaby SM (2012) Solar drying of agricultural products: A review. Renewable and Sustainable Energy Reviews 16(1):37-43. DOI: https://doi.org/10.1016/j.rser.2011.07.134

Hernandez RO, Guerra GLM, Tinôco IFF, Martins JH, Souza C de F, Osorio S JA (2016) Simulation of the internal environment of a post-harvest installation and a solar dryer of coffee. Revista Brasileira de Engenharia Agrícola e Ambiental 20(2):163-168.

Kant K, Shukla A, Sharma A, Kumar A, Jain A (2016) Thermal energy storage based solar drying systems: A review. Innovative Food Science \& Emerging Technologies 34:86-99. DOI:

http://dx.doi.org/10.1016/j.ifset.2016.01.007

Klein SA, Duffie JA, Mitchell JC, Kummer JP, Thornton JW (2014) TRNSYS users manual. Madison, University of Wisconsin, 17 ed.

Lamidi RO, Jiang L, Pathare PB, Wang YD, Roskilly AP (2019) Recent advances in sustainable drying of agricultural produce: A review. Applied Energy 233234:67-385. DOI: https://doi.org/10.1016/j.apenergy.2018.10.044 R

Mekhilef S, Faramarzi SZ, Saidur R, Salam Z (2013) The application of solar technologies for sustainable development of agricultural sector. Renewable and Sustainable Energy Reviews 18:83-594. DOI: https://doi.org/10.1016/j.rser.2012.10.049

Mohanraj M, Chandrasekar P (2008) Drying of copra in a forced convection solar drier. Biosystems Engineering 99(4):604-607. DOI:

https://doi.org/10.1016/j.biosystemseng.2007.12.004 
Murthy MVR (2009) A review of new technologies, models and experimental investigations of solar driers. Renewable and Sustainable Energy Reviews 13:835-844. DOI: https://doi.org/10.1016/j.rser.2008.02.010

Nemś M, Nemś A, Pcyga P (2018) A Granite bed storage for a small solar dryer. Materials 11(10):1969-1984. DOI: https://doi.org/10.3390/ma11101969

Nunes JS, Lins ADF, Gomes JP, Silva WP da, Silva FB da (2017) Influência da temperatura de secagem nas propriedades físico-química de resíduos abacaxi. Agropecuária Técnica 38(1):41-46. DOI: dx.doi.org/10.25066/agrotec.v38i1.29991

Okoroigwe EC, Eke MN, Ugwu HU (2013) Design and evaluation of combined solar and biomass dryer for small and medium enterprises for developing countries. International Journal of Physical Sciences 8(25):13411349. DOI: https://doi.org/10.5897/IJPS2013.3937

Pangavhane DR, Sawhney RL, Sarsavadia PN (2002) Design, development and performance testing of a new natural convection solar dryer. Energy 27(6):579-590. DOI: https://doi.org/10.1016/S0360-5442(02)00005-1
Prakash O, Laguri V, Pandey A, Kumar A, Kumar A (2016) Review on various modelling techniques for the solar dryers. Renewable and Sustainable Energy Reviews 62:396-417. DOI:

http://dx.doi.org/10.1016/j.rser.2016.04.028 1

Queiroz AJ de M, Dantas HJ, Figueirêdo RMF de, Melo K dos S (2011) Solar drying of jack fruit almonds. Engenharia Agrícola 31(6):1150-1161. DOI: http://dx.doi.org/10.1590/S0100-69162011000600012

Shamekhi-Amiri S, Gorji TB, Gorji-Bandpy M, Jahanshahi M (2018) Drying behaviour of lemon balm leaves in an indirect double-pass packed bed forced convection solar dryer system. Case Studies in Thermal Engineering 12:677-686. DOI:

https://doi.org/10.1016/j.csite.2018.08.007

Sonthikun S, Chairat P, Fardsin K, Kirirat P, Kumar A, Tekasakul P (2016) Computational fluid dynamic analysis of innovative design of solar- biomass hybrid dryer: An experimental validation. Renewable Energy 92:185-191. DOI: http://dx.doi.org/10.1016/j.renene.2016.01.095 